\title{
Anecdotal Evidence of the Role of Incubation in the Growth of Business Start-Ups in Uganda
}

\author{
Anthony Tibaingana ${ }^{1}$ \\ ${ }^{1}$ School of Business, College of Business and Management Sciences, Makerere University, Uganda \\ Correspondence: Anthony Tibaingana, School of Business, College of Business and Management Sciences, \\ Makerere University, Uganda.
}

Received: August 5, 2019

Accepted: November 22, 2019

Online Published: November 28, 2019

doi:10.5539/ibr.v13n1p64

URL: https://doi.org/10.5539/ibr.v13n1p64

\begin{abstract}
Although incubation is a well-known and accepted strategy for the growth of business start-ups in Uganda, little is known about its extent. What is known is that the majority of the start-ups fail in less than one year. This study explored the role of incubators on the growth of business start-ups in Uganda. The study interviewed managers of the incubation services and business starts-ups on how they received this support. The study is qualitative and respondents were purposively selected. Key informant interviews and focus group discussions were used to capture the perceptions of the services and how the support enabled the enterprises to grow. The findings show that various services were offered to support the growth of business start-ups. The services ranged from the creation of networks to other business development services such as mentorship, coaching, and marketing. The perceptions of the owners of business start-ups were somewhat mixed because while the majority viewed the support as crucial in the growth of their start-ups, a few others said they did not. Thus, a few owners of business start-up viewed incubators as playing a limited role. The findings are pertinent for policy formulation on the role of business start-ups and for streamlining incubation support processes in emerging economies.
\end{abstract}

Keywords: business incubation, growth, start-ups, Uganda

\section{Introduction}

Business incubation started in the early 1950s in the United States of America as a pathway for the growth of business start-ups (National Business Incubation Association, 1985). The aim of business incubation is to create new successful businesses, wealth, employment and economic development (Ganamotse et. al., 2017; Bruneel, Ratinho, Clarysse \& Groen, 2012; M'Chirgui, 2012; Chandra \& Fealey, 2009; Xu, 2009). Although many countries face challenges in building strong business start-up ecosystems and incubations, big business enterprises can emerge from them once they are properly natured (Yin \& Luo, 2018). By definition, business start-ups are infant and micro with brilliant ideas (Salamzadeh \& KawamoritaKesim, 2015). Rompho (2018) defines a start-up as "a young company, less than 10 years old, with an innovative business model and/or innovative technologies. The reason they are called start-ups is because they must learn how to monetise, validate and test their business model.

Start-ups are very important in many economies because they provide a platform for business trials. They serve as driving factors for national competitiveness in the $21^{\text {st }}$ century (Kim, Lee \& Kim, 2014; Xu, 2009). In Uganda, businesses are developed to contribute to human life. Thus, supporting the growth of business start-ups is critical because they provide goods and services, employment, new innovations to the market, responding to the needs of the communities and paying taxes to governments. Moreover, once businesses are developed then their spill-over effects are always enormous. Hence, nothing is fundamental today to modern human societies than businesses (Reynolds, 2001).

The significance of businesses to human societies is the main reason why new ways of developing and growing them were invented. One such invention is "incubation", which is a cornerstone for the growth of business start-ups (Yin \& Luo, 2018: Bruneel et. al., 2012). Consequently, business incubation has become a global phenomenon. Business incubation offers critical facilities such as access to resources, management training, shared rooms, networks and knowledge (Nair \& Blomquist, 2018; Yin\& Luo, 2018; Bruneel et. al., 2012; Xu, 2009). It contributes to economic development and job creation (Nason \& Wiklund, 2018; Bruneel et. al., 2012). 
The goal of incubation is to reduce the failure rate of business start-ups and to shorten the period and cost of establishing and growing a business. The growth of business start-ups is necessary for economic development and job creation (Nason \& Wiklund, 2018; Bruneel et. al., 2012), and the desired growth is powered by incubators (Bruneel et. al., 2012). Incubators are bedrocks for infant businesses (Bruneel et. al., 2012; Wanklin, 2002); entrepreneurial infrastructure designed to offer support services to stimulate their growth through entrepreneurial ecosystem (Hong \& Lu, 2016; Jamil et. al., 2016; Chandra \& Fealey, 2009); incubation centres bring together an array of skills critical to support the growth of business start-ups; and source of financial support (Harper-Anderson \& Lewis, 2018; Mutambi, 2011; Tötterman \& Sten, 2005).

However, its value depends on how uniquely the support is dispensed to the business start-ups (David-West, Umukoro \& Onuoha, 2018). Some of the factors considered for admission into the lab include; having a good business idea cable of being scaled, availability of financial records, a team managing the business, and robust business proposal (Wanklin, 2002; David-West, Umukoro \& Onuoha, 2018). However, entry barriers do exist which sometimes limit potential businesses from getting incubated.

Nevertheless, given their significant contributions, incubation centres are organised and run by both government and private enterprises (Xiao \& North, 2018). In Uganda, examples of incubators include among others; Innovation Village, Outbox Hub, Hive Colab, Design Lab Kampala, Tech-Buzz Hub, The Mawazo Innovation Hub, Witu Hub, Uganda Research Institute, and the Consortium for enhancing University Responsiveness to Agribusiness Development Limited (CURAD).

This study is based on Barney's (1991) resource-based view theory (RBV) which explains how resources aid in the growth of business start-ups (David-West et. al., 2018; Nason \& Wiklund, 2018). In this study growth was measured through: the number of jobs created; assets acquired, profits made, new branches opened, increase in number of employees, and change in equity value (Davila, Foster \& Gupta, 2003).These measures were selected for the growth of business start-ups because they are easily identifiable and they can portray a clear growth direction. Once business start-ups are able to exhibit such characteristics then it demonstrates that they are growing.

All incubation facilities aim to nurture and grow start-ups in order to reduce the failure rate and possibly reduce unemployment among the youth by stimulating economic development (Chandra \& Fealey, 2009). Despite the burgeoning business incubation centres, their effectiveness in stimulating growth of start-up remains unclear. Yet $80 \%$ to $90 \%$ start-ups started every year fail within the first five years globally and $30 \%$ of the business start-ups in Uganda are not able to operate for more than one year (Ganamotse et. al., 2017; Ishengoma \& Kappel, 2011). Although incubators are seen as a panacea to the growth of business start-ups, no study has examined their contribution in Uganda. Rogova (2014) notes that incubations are places where academic and entrepreneur strength merge. Instead, researches on incubation focus on evaluating their organisation, processes and financial aspects (Wanklin, 2002; Tötterman \& Sten, 2005; Reynolds, 2001) without investigating their actual role in growing enterprises. The findings of this study show that there is minimal contribution that may not justify the huge investment in incubation facilities. In addition, the modus operandi needs to be changed to suit specific context of business start-ups in order to address the peculiar challenges that may emerge.

\subsection{Statement of the Problem}

Incubation is a globally accepted model that stimulates the growth of business start-ups (Rogova, 2014; Mutambi et. al., 2010). Although this may be partly correct, there is paucity of information about the role of incubators in enhancing growth of business start-ups in Uganda. While many incubators exist in Uganda to support the growth of businesses, reports from Uganda government on business start-ups show a decline in the growth of registered businesses from 800,000 in 2001 to 25,000 in 2007 (GoU, 2010). Yet Uganda was ranked as one of the most entrepreneurial countries by Global Entrepreneurship Monitor in 2016. Therefore, the central thesis of this study is to explore the role of incubation in the growth of business start-ups.

\subsection{Objective of the Study}

The overarching objectives of this study are twofold. First, is to profile all the incubators operating in the Kampala area and to review the past and current support given to business start-ups. Kampala is chosen for this study because it is the central business district (CBD) of Uganda where the majority of the incubators are found. Second, is to explore the barriers limiting the growth of incubators. Henceforth, the key questions guiding the study are; how does incubation support the growth of business start-ups? What are the challenges limiting the growth of business start-ups? 


\subsection{Purpose of the Study}

The purpose of the study is to provide anecdotal evidence of the number of incubation centres operating in Kampala through a headcount, enumerating the kind of services they offer to business start-ups and assess the contribution of the evidence to the growth of business start-ups. The research contributes to the role of incubators on the growth of business start-ups.

\section{Literature Review}

By 2012 the National Business Incubation Association estimated the number of global incubators to be 7000 (Weiblen \& Chesbrough, 2015). The rationale of incubation is premised on the vital contribution of business start-ups to economic growth and social contribution through job creation, and increased rates of infant business mortality (Xu, 2009).Incubation of start-up firms is regarded as one of the strongest strategy in supporting business growth in many economies today (David-West et. al., 2018; Xu, 2009). This is because business start-ups face enormous challenges in creating networks, mobilising resources, creating awareness to potential customers, securing legal recognition and negotiating favourable terms with suppliers, among others. Networks are critical to business start-ups because they easily link the products and services to the customer besides facilitating access to expert knowledge and other resources (Bruneel et. al., 2012). Thus, incubators are known to address such complex challenges for the business start-ups in the growth trajectory (Nair \& Blomquist, 2018).

The incubation facilities protect business start-up from harsh realities of operating costs and competition in the market to increase their survival rates (Allen \& McCluskey, 1991; David-West, Umukoro \& Onuoha, 2018; Harper-Anderson\& Lewis, 2018; Xu, 2009). Although there is a strong belief in incubation as a strategy to the growth of business start-ups, the failure rates are still alarming; about half fail in the first five years (Allen \& McCluskey, 1991).

Yet, several studies view incubators as having abilities to spur growth of start-up firms (Harper-Anderson \& Lewis, 2018; Gloor, Woerner \& Zhou, 2018; Jamil et. al., 2016; Rogova, 2014; Mutambi et. al., 2010). Ganamotse et. al., (2017) argue that incubation centres nurture new businesses to grow. However, there are other businesses that have grown from infancy to maturity without necessarily going through business incubation centres. Similarly, even some of the businesses that have been in incubation centres die at infancy (Mas-Verdu et. al., 2015).

\subsection{Types of Business Incubators}

In light of declining economic growth and high rate of unemployment globally, incubation of business start-ups has become a pertinent policy issue in many countries (Fukugawa, 2018; David-West, Umukoro \& Onuoha, 2018; Weiblen \& Chesbrough, 2015; M'Chirgui, 2012). Von Zedtwitz and Grimaldi (2006) identify five archetypes of incubators: regional business incubators, virtual incubators, university incubators, independent commercial incubators, and company-internal incubators. The most common incubators in Uganda are the last three. Such incubators are started with diverse objectives and quite often admit different business start-ups aligned to their original objective. Incubators have evolved over three generations starting with job creation and real estate focus, to intangible services and high-tech (information and communication technology and other technologies) (M'Chirgui, 2012).

Although incubators are motived by increasing the capacity of business start-ups, they are of various types. Nunberger (2017) and M'Chirgui (2012) note that incubators are of three categories: multi-purpose incubators admitting all kinds of business satisfying criteria for entry; specialized incubators which focus on a particular activity, or industry, or sector; and virtual incubators working online. The benefit of allowing incubators in various industries is that it brings innovations which eventually breed the creation of new business ideas. Therefore, it is the incubator's mandate to select start-ups with high growth potential (Davila et. al., 2003; M'Chirgui, 2012).

The other notable categories of incubators are based on the services they offer as the main target of the start-ups. M'Chirgui (2012) provides two specific categories - economic development and technology. Aernoudt (2004) identifies mixed incubators, economic development incubators, technology incubators, social incubators and basic research incubators. These are formed with the object of creating start-ups, improving on regional development, creating entrepreneurs, integrating social categories and blue-sky research (Xu, 2009; Aernoudt, 2004). An incubator should be able to produce business start-ups that can succeed (Xiao \& North, 2018; Aernoudt, 2004).

\subsection{Services Offered by Incubators}

There is a strong belief that incubators support business start-ups to grow by providing supportive infrastructure 
(Mas-Verdu et al., 2015; Xu, 2009). Full-service incubator should be able to offer start-up space, business counselling, business services such as responding to telephone calls, marketing (Nunberger, 2017; Kim, Lee \& Kim, 2014; Xu, 2009). Fukugawa (2018) notes that:

In fact, business incubators provide start-ups not only with physical resources, such as laboratories, offices, internet connection, reception, but also with non-physical resources to solve problems entrepreneurs face.

Hence, such support is aimed at fostering growth. The assumption is that the managers and mentors in the incubation centres have the ability to transfer skills that can initiate business start-ups and to enable them to grow (Fukugawa, 2018). On the other hand, Von Zedtwitz and Grimaldi (2006) argue that incubators help business start-ups by giving them skills to develop business and marketing plans, obtain venture capital, build management teams besides office space and specialised administrative services. These were further summarised into five; physical infrastructure, office support, access to capital, process support, and networking.

Incubators builds social capital for start-ups which is valuable in breaking the liability of newness and establishing social legitimacy known to be difficult for business start-ups (Fukugawa, 2018; Ebbers, 2014; Xu, 2009). In addition, incubators are linked with the growth of start-ups due to the services they offer i.e. access to resources pertinent for their survival (Weiblen \& Chesbrough, 2015). With such support, business start-ups are expected to grow. However, such growth is still not clearly seen despite the increasing numbers of incubation centres.

\subsection{Growth of Start-ups}

The growth in business start-ups is realized where there is an increase in size from one point in time to another (Nason \& Wiklund, 2018).The change in the growth of business start-ups should result into increase in the number of employees, profits, new branches, creation of new jobs and acquisition of capital assets (Davies, Haugh \& Chambers, 2017; Davila et. al., 2003). In this study these variables are used in measuring the growth of business start-ups. Other factors that determine the growth of start-ups such as age, level of education, team of partners, business level, choice of sector, ownership of the firm, access to finance and post-start-up strategy (Thompson Agyapong, Mmieh \& Mordi, 2018) were observed. Accordingly, the variables are acknowledged as pertinent in building capabilities and routines for start-up success (Bruneel et. al., 2012).

\section{Methodology}

The study used a descriptive survey design. Using qualitative approach, interviews and focus group discussions (FGDs) were conducted. A qualitative approach was preferred because of the need for deeper understanding of the contribution of the growth of incubators (Miles \& Huberman, 1994) through the direct feedback of the actors. To realise this objective, the study employed exploratory approach to assess and describe the role of incubators in supporting the growth of business start-ups. This is consistent with Abduh's (2003) model which captures the perceptions of the value and usefulness of the incubation services to business start-ups (Xu, 2009). Also, the study employed a survey method where face-to-face interviews were conducted to collect data. Twenty-two interviews, one in every incubation laboratory, were conducted with the Chief Executives Officers (CEOs) of the business start-ups. The interviews with the CEOs (i.e., owners) of the incubators aimed to get an overview of the services they offered. These were able to give vivid account of their experiences of owning and managing a business. Twenty-two FGDs were conducted in every laboratory. Each FGD consisted of 6 to 10 members based on the period they had stayed in the lab. The FGDs were meant to collect information on their perception of the services given in relation to the growth of the businesses. They were also able to highlight the challenges confronting the businesses.

An exploratory design was also used because incubation is still a new phenomenon in Uganda thus its understanding requires talking and recording participants' experiences (Chandra \& Fealey, 2009; Tötterman \& Sten, 2005). As well, many substantive issues in entrepreneurship are hardly addressed (Tötterman \& Sten, 2005). Thus, the barriers and performance of business start-ups and the overall contribution of the incubators that host the majority of business start-up in Kampala district were explored and reported on. Kampala was chosen because it is the commercial heartland of Uganda where most business activities, including incubators, take place (Orobia et. al., 2013).

To study the businesses, a list of incubation centres was obtained from the registrar of incubators. Using snow-balling the incubators gave the contacts of other incubators. Then, the managers of the incubators were contacted to fix appointments. After securing an appointment, each incubation centre was visited to get an overview of services they offered to the start-ups. Thereafter, the list of the start-ups supported by the incubation centre (current and previous) was obtained to help in contacting the owners of the start-ups to engage in a FGD. The purpose of the FGD was to find out how the support received by the start-ups from the incubation centres 
supported their growth.

Before visiting the business start-ups, a semi-structured interview guide with open-ended questions (to stimulate the discussion and allow for probing) (Turner, 2010) relating to growth was developed. As it is for most qualitative interviews more questions were developed during the interview while others were adopted from similar studies to guide the discussion during the FGD. The FGDs comprised of start-up proprietors/owners/managers because they have the experience and they exhibited homogeneous characteristics (Powell \& Single, 1996; Reisner et. al., 2017).

The study was three-phased. Phase one started with profiling the incubators in Kampala where they are located. In phase two we interviewed the proprietors/owner/managers of the incubation centres. While in phase three carried out FGDs with the start-up firm owners. Data analysis was done aided by Nvivo 10 software. Before the data was analysed, it was arranged according to themes, edited to eliminate unwanted information, and then transcribed. The analysis started from the field where phrases were recorded as verbatim quotes.

\section{Results}

In this study Miles and Huberman's (1984) techniques of analysing, displaying and managing qualitative data such as tables and graphs were used. The findings from profiling incubators reveal that there are many incubators operating in Kampala (Table1). The National Population Census Report of 2014 estimated Kampala's population at about 1.5 million people. This partly explains the reason for the heavy concentration of incubators in Kampala. More so, Kampala is the central business district (CBD) of Uganda. Administratively Kampala is divided into five divisions (Kampala central, Nakawa, Rubaga, Kawempe and Makindye). It is the study objective to explore the numbers of incubators in the various divisions. The findings in Table 1 show the distribution of incubation facilities in Kampala. 
Table 1. Physical location of the incubator by division

\begin{tabular}{|c|c|c|c|}
\hline Name of the incubation LAB & Physical location in Kampala & Divisionlocation & $\begin{array}{l}\text { Sex of the } \\
\text { LAB } \\
\text { proprietor }\end{array}$ \\
\hline Renewable Business Incubator & $\begin{array}{l}\text { Makerere College of Art Design and } \\
\text { Technology }\end{array}$ & Kawempe & Female \\
\hline Venture Labs & Binayomba Rd, Bugolobi & Nakawa & Male \\
\hline Hive Colab & Kanjokya Street, Kamwokya & $\begin{array}{c}\text { Kampala } \\
\text { Central }\end{array}$ & $\begin{array}{l}\text { Male and } \\
\text { Female }\end{array}$ \\
\hline Outbox & Soliz House & $\begin{array}{c}\text { Kampala } \\
\text { Central }\end{array}$ & Male \\
\hline $\begin{array}{l}\text { Food Technology Business } \\
\text { Incubator }\end{array}$ & $\begin{array}{l}\text { Makerere College of Agriculture and } \\
\text { Environmental Sciences Food } \\
\text { Science Centre }\end{array}$ & Kawempe & Male \\
\hline Business Development Centre & Forest Mall, Lugogo & Nakawa & Male \\
\hline MUBS Incubation Centre & $\begin{array}{c}\text { Makerere University Business } \\
\text { School }\end{array}$ & Nakawa & Female \\
\hline Go Big Hub & Tirupati Mazima Mall & Makindye & Male \\
\hline Yunus Social Business & Kanjokya Street, Kamwokya & Kampala central & Male \\
\hline Resilient Africa Network & Upper Kololo Terrace & Kampala central & Male \\
\hline TEXFAD & BweyogereIndustral Area Road & Nakawa & Male \\
\hline Techbuzz & Kigobe Road, NajimMall,Ntinda & Nakawa & Male \\
\hline Design Hub & Sixth Street Industrial Area & Nakawa & Female \\
\hline Artificial Intelligence Lab & $\begin{array}{l}\text { MUK College of Computing and } \\
\text { Information Sciences Block B Level } \\
\text { six }\end{array}$ & Kawempe & Male \\
\hline The Square & Third Street Industrial Area & Nakawa & $\begin{array}{l}\text { Male and } \\
\text { Female }\end{array}$ \\
\hline $\begin{array}{l}\text { Makerere university Innovation \& } \\
\text { Incubation Centre }\end{array}$ & $\begin{array}{c}\text { Makerere College of Computing and } \\
\text { Information Sciences Block B Level } \\
\text { five }\end{array}$ & Kawempe & Male \\
\hline Software Business Incubation & $\begin{array}{l}\text { MUK College of Computing and } \\
\text { Information Sciences Block B Level } \\
\text { six }\end{array}$ & Kawempe & Male \\
\hline $\begin{array}{l}\text { Consortium for enhancing } \\
\text { University Responsiveness to } \\
\text { Agribusiness Development } \\
\text { (CURAD) }\end{array}$ & Kabanyolo, Gayaza & Kawempe & Male \\
\hline The Space Hub & Lugogo Bypass & Nakawa & Male \\
\hline UTAMU Incubation Centre & Kiswa, Bugolobi & Nakawa & Male \\
\hline Open Brain & Luthuli Avenue Bugolobi & Nakawa & Male \\
\hline Tech Hub & Park Royale Building & Kampala central & Male \\
\hline Imuka ventures & $\begin{array}{c}\text { Makerere University, } 1^{\text {st }} \text { Floor New } \\
\text { FTBIC Building Makerere } \\
\text { University }\end{array}$ & Kawempe & Male \\
\hline
\end{tabular}


Table 1 clearly shows that the majority of the incubation proprietors/managers are male. This is so because fewer women engage in business. Most of the time women are at home taking care of the children. The count in Table 1 provides distribution of incubators in CBD. It shows that the majority (10) of the business start-ups were situated in Nakawa, 6 in Kawempe, 5 in Kampala central, 1 in Makindye and none in Rubaga division. The high concentration of incubators in Nakawa division is justified by the many industries in the area. Nakawa is the industrial area of Uganda. Thus, the incubators target business start-ups that want to imitate the mature existing industries. Besides, there is a spill-over effect from existing industries and this stimulates innovations. Those in Kawempe are premised on the presence of Makerere University since they are mainly housed at the university.

\subsection{Services Offered}

The profile of the results indicates that incubators have no collaborations and don't work together. Hence, many were ignorant about other incubators. Consequently, some start-ups keep on moving from one incubator to another. This has made some start-ups to concentrate on prize-winning as a business in various incubation centres based on the same idea. This explains why some start-ups stay in different incubation centres for a long time. Thus, the growth of start-ups cannot be premised on the support of a single incubator. However, the CEO of Ensibuuko, an alumni incubator, saw the support from incubators as useful to the growth of business start-ups in the following words:

Outbox ensured that we did not burn out of resources, by introducing us to potential funding partners that enabled us to build a product, test the product, build our team and gain traction. Outbox helped us find our first funding at a very critical time.

Although the mission of incubators is to provide support for the growth of business start-ups, this is not realized by all. Some of them were not in agreement that they received significant support for growth. Some compared their support as minimal such as space provision. Those with this view argued that space was not the sole reason for joining start-ups because they expected a lot more in areas like networking and financial support.

In the food technology and incubation centre, the lab manager noted that they provide support in the area of food science. He argued that the centre provides a variety of services depending on the needs of the business start-ups. $\mathrm{He}$ added that the centre gives technical knowledge, marketing, product development, good management practices, space, power, water, and processing and packaging skills. The services offered are important in supporting start-ups, for example, some business start-ups have grown into big businesses like; Biz Multiple, AEN Uganda limited, Lena Uganda, Samaline, Smart food and Nutril Uganda limited. All these are big companies that are up and running and employing other young people.

Furthermore, business start-ups received grants, and subsidized support services such as access to an expert advisory (e.g., legal, marketing and finance). These services are sometimes charged a fee to promote their proper use. The services offered are critical to business start-ups because of the ability to build an understanding of how to run a business. For example, a manager in MIIC lab said:

Why we charge start-ups fees for space is to prepare them for rent in future. Business start-ups should know that they have to improvise and pay rent. However, our rent here is subsidized. In addition, space in the lab is given after a thorough review of applicants by a panel of experts to ensure quality start-ups get into the lab.

The owners of business start-ups are trained and mentored in skills that are critical for their growth, such as time-keeping, record management, human resource and financial management, and marketing. These skills are also highly needed because of the culturally diverse customer base. However, the huge challenge experienced in the labs is that of coaches who offer voluntary services thus making it extremely difficult to demand high quality services. In addition, because some coaches are not trained teachers, they offer poor quality mentorship. These impediments are not good for the growth of business start-ups.

The majority of the incubators offered relatively similar services and admitted almost the same kind of business start-ups. The Consortium for enhancing University Responsiveness to Agribusiness Development Limited (CURAD) which was started with the mission of supporting agribusiness also offered services like production facilities, product development, technical support, work station and revolving fund. The services enabled the growth of business start-ups by building and improving the quality of their products, marketing and providing access to markets and financial networks. Unlike other incubators, CURAD, Imuka ventures and other incubators charge application fees to business start-ups interested in joining the facility. The fees which are charged is meant to encourage commitment. Besides, it commits the incubators to deliver based on their promise. It equally makes business start-ups to appreciate the value given. However, it is regarded as a limiting factor to those unable to pay (Wanklin, 2002; David-West et. al., 2018). 
On the question of the perception regarding the support obtained by business start-ups from incubation, they were specifically asked about the general services - i.e., the focus was on business networks, access to funding, space provision, coaching, marketing support and whether incubators have the ability to support successful entrepreneurs (see figure 1).

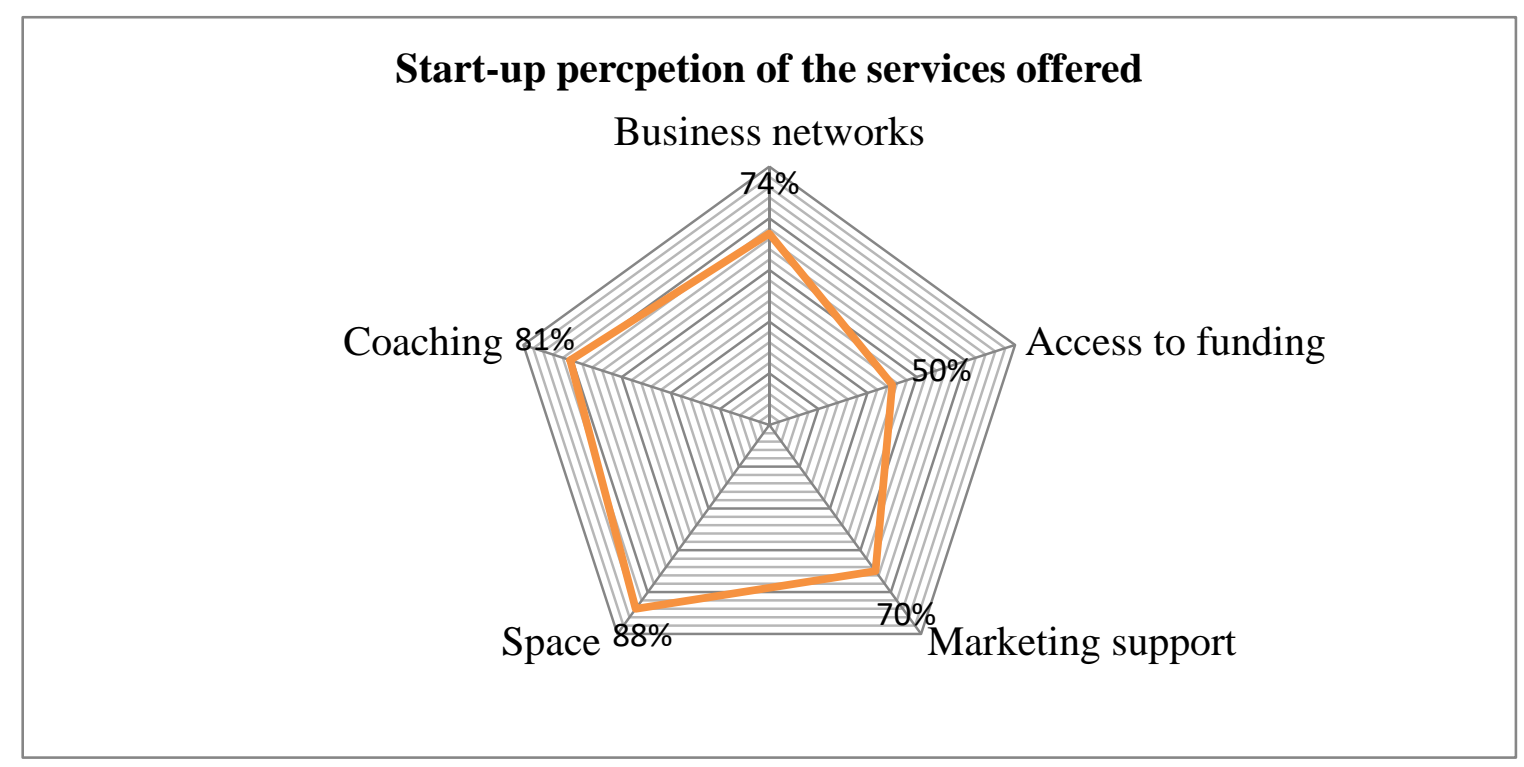

Figure 1. Perception of start-ups on incubation support

The findings in figure 1 show that incubation centres were providing support to business start-ups. However, few successful entrepreneurs were emerging from the support rendered by the incubators. This is due to the numbers that are capable of being accommodated in the lab. Many incubators hardly accommodated more than ten start-ups. However, the support in the form of space was recognized as key in supporting business start-ups (figure 1). As a result some start-ups were able to access funding from financial institutions.More so, start-ups are exposed to business connection during their stay in the incubation centres.

The majority of the start-ups appreciated the coaching, marketing support, internet, exposure, and mentorship because it played significant roles in the growth process. The support enabled the business start-ups to acquire assets, register and incorporate their businesses, create a socialization platform, having a physical address, and new branches. For example, a business proprietor stated that:

With software incubation support we were able to develop a number of services for sale to our clients. As a software developer, we developed Nandoz which is selling globally, creativity in motion that is sold locally, and we have managed to expand to Kenya and Rwanda. In addition, new jobs were created for our fellow youth interested in the software business (Manager Creativity in Motion).

\subsection{Other Factors Accelerating the Growth of Start-ups}

The study investigated other factors that account for the growth of business start-ups such as age, level of education of the proprietor, nature of the team of the partners, business level, choice of the sector, ownership, access to finance, and post-incubation support. The findings in figure 2 show some of the other factors that are important for the growth of the business start-ups besides the incubation support. 


\section{Other factors accelerating start-up growth}

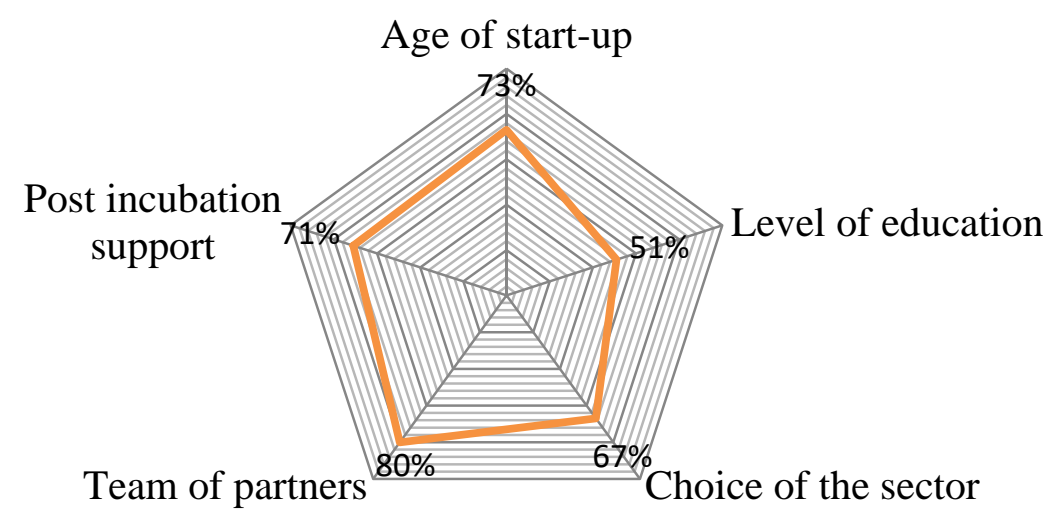

Figure 2. Respondents' perceptions of the factors supporting the growth of business start-ups

The factors illustrated in figure 2 show that access to finance, age of start-ups (period start-ups has existed), level of education of the owner of the start-ups, post-incubation support and team partnership were important determinants of growth of the business start-ups. For example, team partner, post-incubation support and age of the start-up was considered more important than the level of education and choice of the sector in the growth of business start-ups. Thus, the growth of the business start-ups cannot be attributed to a single factor but rather a plethora of factors. As a result, one of the owners of the business start-ups in the FGD observed that:

Incubation centres were only giving basic services but the real growth of the start-up business rest in the way one will deal with his/her clients, where you will be located, how you will satisfy your customers and the amount of money in terms of capital you will access. For me I think we should be given post-incubation support to make our business more strong.

\subsection{Perceptions on the Growth of Start-ups}

In measuring the growth of business start-ups, five variables were used, namely; number of employees, increase in profits made, capital assets acquired, jobs created, and new branches opened (Davila et. al, 2003). The findings in figure 3 show the perception of the growth of the business start-ups.

\section{Perception on growth of start-ups}

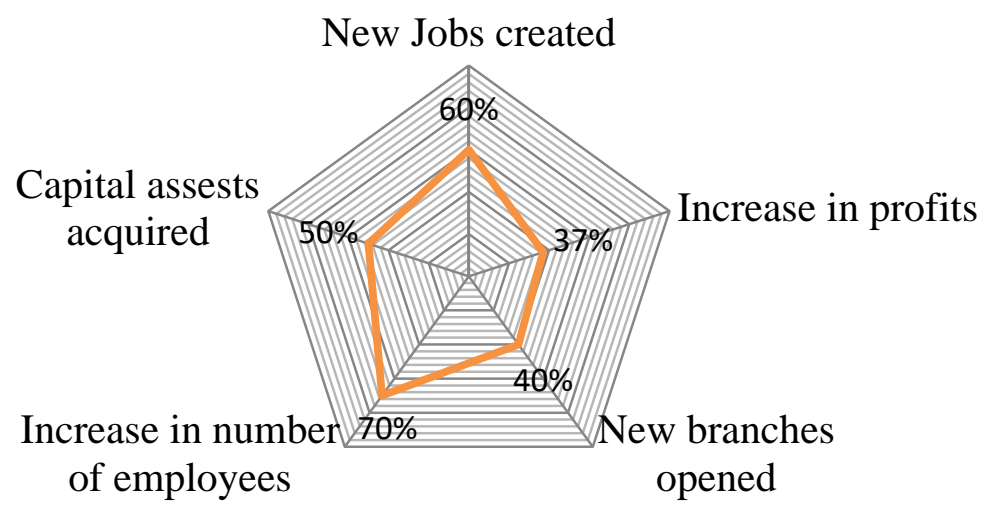

Figure 3. Respondents' perception of the growth of business start-ups 
The findings of the study show that the growth of business start-ups is less supported by incubation. The shrinking line in figure 3 shows minimal support. As the line moves out wards, it indicates much support. Therefore, the respondent's perception was enlisted on jobs created which show $60 \%$, capital asset acquired at $50 \%$, new staff hired was high at $70 \%$ while profits made was the least at $37 \%$. The perception of support of business start-ups was minimal. Many argued that they go to incubation centres mainly because of the space which is provided. This clearly demonstrates that business start-ups get minimal support from incubation. More so, the growth was being realized in the number of those employed as opposed to acquiring capital assets that are pertinent in the business' growth strategy.

\subsection{Barriers Limiting the Growth of Start-ups}

Despite the growth realized by many business start-ups as a result of incubation support, there are various bottlenecks impeding their growth. The findings from the FGDs show that access to finance is one of the major inhibiting factors to the growth of business start-ups. It was argued that even when start-ups come up with a good business idea up to concept development stage, inadequate funds becomes a challenge. In addition, most financial lending institutions hardly trust business start-ups because they lack security in form of collateral. Consequently, this limits the ability of the business start-ups to peruse lucrative opportunities that may expedite their growth. This can be dealt with by securing seed capital for promising business ideas or supporting start-ups to secure loans from financial institutions.

The findings show that the attitude (entrepreneurial mind-set) of the owners of business start-ups is another critical factor limiting growth. Therefore, most of the business start-ups are initiated as a stop-gap measure for job search (a necessity as opposed to opportunity) and once a job is secured then the enterprise is left to die. This limits the focus of the proprietor because when a job is secured then the business may continue as a secondary activity or it may be closed. Thus, the proprietors choose to remain small with no ambition to grow simply because they feel know they will soon abandon the business. Consequently, their attitude affects the motivation and impact to grow the business.

Although the incubation centres are interested in changing the attitude of the proprietors, it has kept the business start-ups small, thus, affecting their growth. The attitude also affects their ability to find hardworking employees because most of them are sourced from the youth themselves who want prompt pay. So, when the business start-up is unable to do so on time, they quit. Unfortunately, attitude, which is embedded in culture and background and takes long to change, has continued to affect the growth of the business start-ups in Uganda. A respondent in the FGD stated that:

The attitude issue is not only one-sided, it also affects us from the customer's point of view. Many customers do not trust our products or services; they feel they are of poor quality and this affects our sales. Even other companies don't want to contact us because they feel we are not in position to deliver on big assignments which affect our income and keep us small.

The findings show other factors inhibiting the growth of business start-ups such as cost of operation which greatly affects how the business is run (see Figure 4) - for example, the costs incurred in legalizing the business and the taxes levied - the nature of products or services offered some of which are easily imitated, the industry like information technology that is growing very fast, week managerial experience which affects the way decisions are made and quite often cause management mistakes, and conflict among the owners resulting from profit and loss sharing. In the FGD, an owner of a business start-up said thus:

I have had many quarrels with my partner because he wanted us to buy a car and yet it was not a priority so we ended up parting ways and now I work with my employees because I retained the business name and customers.

In the FGD, many barriers interfere with the growth of start-ups (see figure 4). 


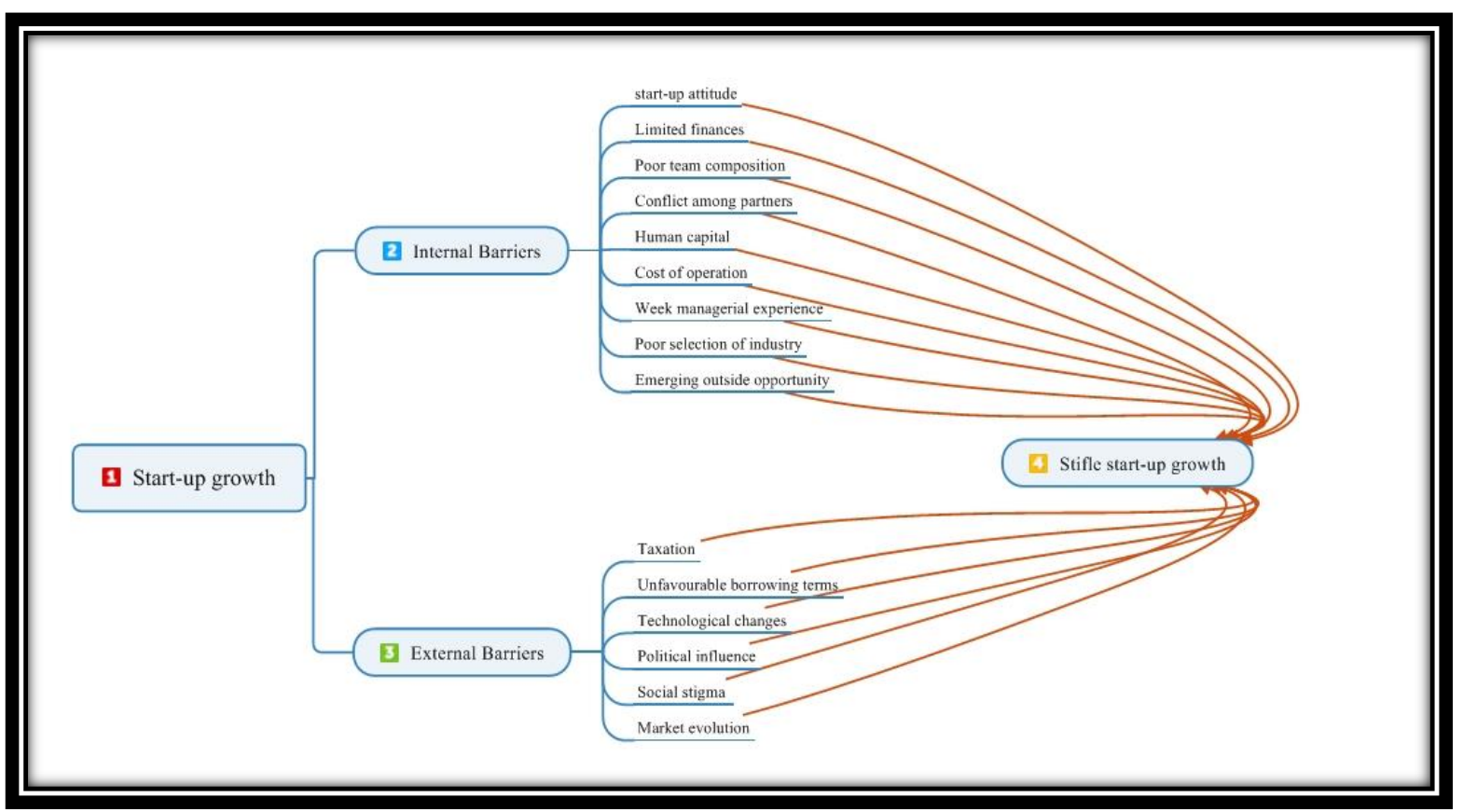

Figure 4. Summary of barriers precluding start-up growth

Figure 4 demonstrates that the barriers are both internal and external. However, unlike the external barriers where business start-ups and incubation labs have no control, the internal barriers are capable of being managed within the ambit of incubation labs.

\section{Discussion of the Findings}

The findings demonstrate that incubators are critical in supporting business start-ups. Indeed, many would actually die if they did not receive such support. Therefore, the policy-makers should look at the start-ups as having the potential to create and stimulate economic development through business incubation (Bruneel et. al., 2012). However, the support from incubation per se is insufficient for the growth of business start-ups. Multiple strategies to support start-ups were identified which when properly designed and implemented, can promote the growth of business start-ups (Mas-Verdu et. al., 2015). It is, therefore, crucial to focus on key success factors that must be put into consideration during vulnerable period of nurturing business start-ups. Indeed, in Japan the competence of managers and mentors was found to be extremely important for the growth of business start-ups (Fukugawas, 2018).

The findings unearthed the fact that the business start-ups unanimously demonstrated that the support offered to incubators created an opportunity for them to network and build strong links that they would have failed to achieve or take long to create. The implication behind this finding is that the support was a key to growth of business start-ups, thus, confirming our working proposition.

In other words, the findings show that the services offered by incubators are critical support to the business start-ups, for example, space, network, finance, legal and marketing. In general, all the services offered were pertinent but not sufficient condition for long-term survival of the business start-ups. This explains why incubation is also evolving from incubation to acceleration to angel investor (Yin \& Luo, 2018).

However, there are various challenges inhibiting the growth of business start-ups in all the incubators which require urgent attention. Their uniqueness necessitates a differential support mechanism other than providing the same services to all the business start-ups. It was observed that most incubators provided neutral services to all business start-ups without due consideration to their size and growth stage. However, the major drawback for business start-ups was the pressure to make money from the coaches and mentors. This derails the focus on the growth of the businesses to focusing on sales. Sales alone cannot yield growth because it strains the capacity of the business start-ups to strategize for future growth. This problem arose due to the calibre of the coaches, the majority of who came from mature companies, who were seen as incapable of understanding the growth needs of the business start-ups. 
Also, poor selection of business start-ups was seen as being responsible for their poor growth. A few CEOs who were interviewed admitted that the labs manufactured poor products. This situation can be resolved by coming up with clear selection criteria and using experienced staff to select appropriate business start-ups for incubation in the labs.

\section{Conclusion}

In conclusion, the findings show that support to incubators is important to the growth of business start-ups. However, such support needed to be improved upon. This is because of the various internal and external factors that limited the growth of business start-ups. For example, although business start-ups rated post-lab support as crucial to their growth, this was not given by many incubation centres. The findings further show that business start-ups need to pay for the services they received from the incubation centres because when it is provided free, it is taken for granted.

This study, therefore, recommends that incubators should start looking out for the best business start-ups other than depending on self-offers. In addition, business start-ups need to be trained and carefully selected. Also, they should pay for incubation services so as to demand for quality services from incubation centres.

\section{Acknowledgement}

The author is grateful to Makerere University -SIDA Research program and the College of Business and Management Sciences (CoBAMS) for sponsoring the study.

\section{References}

Aernoudt, R. (2004). Incubators: tool for entrepreneurship? Small business economics, 23(2), 127-135. https://doi.org/10.1023/B:SBEJ.0000027665.54173.23

Allen, D. N., \& McCluskey, R. (1991). Structure, policy, services, and performance in the business incubator industry. Entrepreneurship Theory and Practice, 15(2), 61-77. https://doi.org/10.1177/104225879101500207

Bruneel, J., Ratinho, T., Clarysse, B., \& Groen, A. (2012). The Evolution of Business Incubators: Comparing demand and supply of business incubation services across different incubator generations. Technovation, 32(2), 110-121. https://doi.org/10.1016/j.technovation.2011.11.003

Chandra, A., \& Fealey, T. (2009). Business incubation in the United States, China and Brazil: a comparison of role of government, incubator funding and financial services. International Journal of Entrepreneurship, 13, 67.

David-West, O., Umukoro, I. O., \& Onuoha, R. O. (2018). Platforms in Sub-Saharan Africa: startup models and the role of business incubation. Journal of Intellectual Capital, 19(3), 581-616. https://doi.org/10.1108/JIC-12-2016-0134

Davies, I. A., Haugh, H., \& Chambers, L. (2017). Barriers to social enterprise growth. Journal of Small Business Management.

Davila, A., Foster, G., \& Gupta, M. (2003).Venture capital financing and the growth of startup firms. Journal of business venturing, 18(6), 689-708. https://doi.org/10.1016/S0883-9026(02)00127-1

Ebbers, J. (2014). Networking behavior and contracting relationships among entrepreneurs in business incubators. Entrepreneurship Theory and Practice, 38(5), 1159-1181. https://doi.org/10.1111/etap.12032

Evans, D. S. (1987). Tests of alternative theories of firm growth. Journal of Political Economy, 95(4), 657-674. https://doi.org/10.1086/261480

Frick, W. (2016). The U.S. startup economy is in both better and worse shape than we thought. Harvard Buisness Review. Retrieved January 21, 2017, from https://hbr.org/2016/03/the-u-s-startup-economy-is-in-both-better-and-worse-shape-than-we-thought

Fukugawa, N. (2018). Is the impact of incubator's ability on incubation performance contingent on technologies and life cycle stages of startups? evidence from Japan. International Entrepreneurship and Management Journal, 14(2), 457-478. https://doi.org/10.1007/s11365-017-0468-1

Ishengoma, E. K., \& Kappel, R. (2011).Business environment and growth potential of micro and small manufacturing enterprises in Uganda. African Development Review, 23(3), 352-365. https://doi.org/10.1111/j.1467-8268.2011.00291.x

Ganamotse, G. N., Samuelsson, M., Abankwah, R. M., Anthony, T., \& Mphela, T. (2017). The Emerging 
Properties of Business Accelerators: The Case of Botswana, Namibia and Uganda Global Business Labs. Journal of Entrepreneurship and Innovation in Emerging Economies, 3(1), 16-40. https://doi.org/10.1177/2393957516684469

GoU. (2010). National Development Plan (2010/11-2014/15). Retrieved from www.finance.go.ug

Harper-Anderson, E., \& Lewis, D. A. (2018). What Makes Business Incubation Work? Measuring the Influence of Incubator Quality and Regional Capacity on Incubator Outcomes. Economic Development Quarterly, 32(1), 60-77. https://doi.org/10.1177/0891242417741961

Hong, J., \& Lu, J. (2016). Assessing the effectiveness of business incubators in fostering SMEs: evidence from China. International Journal of Entrepreneurship and Innovation Management, 20(1-2), 45-60. https://doi.org/10.1504/IJEIM.2016.075298

Jamil, F., Ismail, K., Siddique, M., Khan, M. M., Kazi, A. G., \& Qureshi, M. I. (2016). Business incubators in Asian developing countries. International Review of Management and Marketing, 6(4S).

Kim, H. S., Lee, Y., \& Kim, H. R. (2014). Technology venture startup invigoration strategy for building infrastructures for the business startup ecosystem. In Advances in Computer Science and its Applications (pp. 1303-1309). Springer, Berlin, Heidelberg. https://doi.org/10.1007/978-3-642-41674-3_180

Mas-Verdu, F., Ribeiro-Soriano, D., \& Roig-Tierno, N. (2015). Firm survival: The role of incubators and business characteristics. Journal of Business Research, 68(4), 793-796. http://dx.doi.org/10.1016/jbusres.2014.11.030

M Chirgui, Z. (2012). Assessing the performance of business incubators: recent France evidence. Business and Management Research, 1(1), 62. https://doi.org/10.5430/bmr.v1n1p62

Miles, M. B., \& Huberman, A. M. (1994). Qualitative Data Analysis: An Expanded Sourcebook (2nd ed.). Sage, Thousand Oaks, CA.

Mutambi, J., Byaruhanga, J. K., Trojer, L., \& Buhwed, K. B. (2010). Research on the state of business incubation systems in different countries: lessons for Uganda. African Journal of science, technology, innovation and development, 2(2), 190-214.

Mutambi, J. (2011). Stimulating industrial development in Uganda through open innovation business incubators (Doctoral dissertation, Blekinge Institute of Technology).

Nair, S., \& Blomquist, T. (2018). Failure prevention and management in business incubation: practices towards a scalable business model. Technology Analysis \& Strategic Management, 1-13. https://doi.org/10.1080/09537325.2018.1495325

Nason, R. S., \& Wiklund, J. (2018). An assessment of resource-based theorizing on firm growth and suggestions for the future. Journal of Management, 44(1), 32-60. https://doi.org/10.1177/0149206315610635

Nunberger, I. (2017). Business incubation and start-ups in the ICT sector.

Orobia, L. A., Byabashaija, W., Munene, J. C., Sejjaaka, S. K., \& Musinguzi, D. (2013). How do small business owners manage working capital in an emerging economy? A qualitative inquiry. Qualitative Research in Accounting \& Management, 10(2), 127-143. https://doi.org/10.1108/QRAM-02-2012-0008

Powell, R. A., \& Single, H. M. (1996). Focus groups. International journal for quality in health care, 8(5), 499-504. https://doi.org/10.1093/intqhc/8.5.499

Reisner, S. L., Randazzo, R. K., White Hughto, J. M., Peitzmeier, S., DuBois, L. Z., Pardee, D. J., ... Potter, J. (2017). Sensitive Health Topics With Underserved Patient Populations: Methodological Considerations for Online Focus Group Discussions. Qualitative Health Research. https://doi.org/10.1177/1049732317705355

Reynolds, P. D. (2001). National panel study of US business startups: Background and methodology. In Databases for the Study of Entrepreneurship (pp. 153-227). Emerald Group Publishing Limited. https://doi.org/10.1016/S1074-7540(00)04006-X

Rogova, E. (2014). The effectiveness of business incubators as the element of the universities spin-off strategy in Russia. International Journal of Technology Management \& Sustainable Development, 13(3), 265-281. https://doi.org/10.1386/tmsd.13.3.265_1

Rompho, N. (2018). Operational performance measures for startups. Measuring Business Excellence, 22(1), 31-41. https://doi.org/10.1108/MBE-06-2017-0028

Salamzadeh, A., \& KawamoritaKesim, H. (2015). Startup Companies: Life Cycle and Challenges. https://doi.org/10.2139/ssrn.2628861 
Tötterman, H., \& Sten, J. (2005). Start-ups: Business incubation and social capital. International small business journal, 23(5), 487-511. https://doi.org/10.1177/0266242605055909

Thompson, A. G., Mmieh, F., \& Mordi, C. (2018). Factors influencing the growth of SMEs: The case of Ghana. Thunderbird International Business Review, 60(4), 549-563. https://doi.org/10.1002/tie.21945

Turner III, D. W. (2010). Qualitative interview design: A practical guide for novice investigators. The qualitative report, 15(3), 754-760.

Von Zedtwitz, M., \& Grimaldi, R. (2006). Are service profiles incubator-specific? Results from an empirical investigation in Italy. The Journal of Technology Transfer, 31(4), 459-468. https://doi.org/10.1007/s10961-006-0007-7

Wanklin, T. (2002). Understanding business incubation. Nature biotechnology, 20(6s), BE23. https://doi.org/10.1038/nbt0602supp-BE23

Weiblen, T., \& Chesbrough, H. W. (2015).Engaging with startups to enhance corporate innovation.California Management Review, 57(2), 66-90. https://doi.org/10.1525/cmr.2015.57.2.66

Xiao, L., \& North, D. (2018). The role of Technological Business Incubators in supporting business innovation in China: a case of regional adaptability?. Entrepreneurship \& Regional Development, 30(1-2), 29-57. https://doi.org/10.1080/08985626.2017.1364789

$\mathrm{Xu}, \mathrm{L}$. (2009). Business incubation in China: Effectiveness and perceived contributions to tenant enterprises. Management Research Review, 33(1), 90-99. https://doi.org/10.1108/01409171011011599

Yin, B., \& Luo, J. (2018). How Do Accelerators Select Startups? Shifting Decision Criteria Across Stages. IEEE Transactions on Engineering Management. https://doi.org/10.1109/TEM.2018.2791501

\section{Interview Guide:}

1. What is the name of the incubator?

2. When did the incubators start?

3. What is the mission of the incubation?

4. What was the reason for starting the incubator? (look at the mission statement).

5. How much space do you provide in terms of square metres?

6. Talk about your experience about incubation for business start-ups.

7. What kind of business do you accept in to the incubation? And why?

8. What services does the incubator provide to business start-ups?

9. Do the services offered to business start-ups help them to perform better?

10. How are services provided? Who provides the services e.g. who does the coaching?

11. Do you follow up on the business start-ups after they have left the incubation? If yes why? If no why not?

\section{Focus Group Discussion Guide:}

1. Talk about the type of businesses that you are running.

2. Why did you join the incubation?

3. Talk about your experience in the incubation.

4. Have you created new jobs ever since you joined the incubation? If yes which ones?

5. Have you acquired more assets since you joined the lab?

6. Has the number of your employees increased as a result of being in the incubation?

7. Has your sales increased due to your presence in the incubation?

8. Have you created new branches resulting from the support in the incubation?

9. What are the benefits of joining the incubation lab?

10. What do you require to grow your business start-ups? 
11. What type of business are you engaged in?

12. What barriers impede your business growth?

13. What is your perception on the following factors in explaining your business growth? (a) Age, (b) level of education, (c) team of partners, (d) business level, (e) choice of sector, (f) ownership of the firm, (g) access to finance and (h) post start-up strategy.

14. In your view, what are the barriers to growth of business start-ups?

\section{Copyrights}

Copyright for this article is retained by the author(s), with first publication rights granted to the journal.

This is an open-access article distributed under the terms and conditions of the Creative Commons Attribution license (http://creativecommons.org/licenses/by/4.0/). 